\title{
Using Cornell system and NRC dairy model to predict nutrient supply from new super-genotype of oat grain in comparison with two normal varieties of oat
}

\author{
Z. Niu ${ }^{1}$, B.G. Rossnagel ${ }^{2}$ and P. Yu ${ }^{1,3}$ \\ University of Saskatchewan, \\ ${ }^{1}$ Department of Animal and Poultry Science, \\ ${ }^{2}$ Crop Development Centre \\ Saskatoon, S7N 5A8, Canada
}

\begin{abstract}
The objectives of this study were to use Cornell system (CNCPS) and NRC-2001 dairy model to predict nutrient supply from super-genotype in comparison with two normal varieties of oat grains. Six oat samples comprised of 3 cultivars (Super-genotype: CDC SO-I and Normal: CDC Dancer, Derby) grown over two years (2005 and 2006) were obtained from the Crop Development Centre at the University of Saskatchewan. Protein and carbohydrate fractions were determined using the CNCPS system. Total digestible nutrient (TDN) and energy values (TDN1x, DE3x, ME3x, NE $3 x$, $\mathrm{DE} 4 \mathrm{x}, \mathrm{ME} 4 \mathrm{x}, \mathrm{NE}_{\mathrm{L}} 4 \mathrm{x}$ of dairy, $\mathrm{ME}, \mathrm{NE}_{\mathrm{m}}$ and $\mathrm{NE}_{\mathrm{g}}$ of beef) at maintenance and production levels for both dairy and beef cattle were determined using NRC-2001 and NRC-1996 chemical approaches. The detailed results are reported. The information obtained from this study will be useful for oat breeders, feed and livestock industries.
\end{abstract}

KEY WORDS: nutrient modeling, energy, super-genotype, oat

\section{INTRODUCTION}

Oat samples vary considerably in nutrient composition. Much of the variation arises from genotype, growth environment, and interaction between environment and genotype. Other differences may result from harvest conditions, storage, and post-harvest treatments or other processes that the crop is subject to before final use. Further apparent differences in composition may be a result of variation in

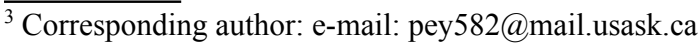


analytical methods (Fuhr, 2006). Early studies indicated that oat used as an energy source for dairy cattle had no advantage over other cereal grains (Fisher and Logan, 1969; Tommervik and Waldern, 1969; Schingoethe et al., 1982; Moran, 1983, 1986; Martin and Thomas, 1987) due to high hull content ranging from 20 to $30 \%$ (Crosbie et al., 1985). Oat hulls are fibrous and contain substantial amounts of indigestible lignin. Lignin impedes the digestion of associated nutrients. However, oat has higher lipid content and can have an advantage over other cereals in terms of energy content (Fuhr, 2006). Recent developments by The Crop Development Centre, University of Saskatchewan has showed promise for oat use in dairy rations. This type of oat contains low-lignin hull (LLH) and highfat groat (HOG), and is low in acid detergent lignin (ADL) and has greater ruminal degradability, thus, LLH-HOG oat should be a superior oat for feeding dairy cattle (Fuhr, 2006). The objectives of this study were to use Cornell system (CNCPS) and NRC-2001 dairy model to predict protein and carbohydrate fractions and nutrient supply from super-genotype (CDC SO-I) in comparison with two normal varieties of oat grains.

\section{MATERIAL AND METHODS}

\section{Oats samples}

Six oat samples, the cultivars CDC Dancer, Derby and CDC SO-I grown over two years (2005 and 2006) were provided by the Crop Development Centre, University of Saskatchewan. They are not genetically modified oats.

\section{Chemical analysis}

Chemical analyses included DM, EE, ash, CP, starch, NDF, ADF, ADL, SCP, NPN, NDIN, ADIN, were determined (AOAC, 1990; Van Soest et al., 1991; Licitra et al., 1996; McCleary et al., 1997).

Sub-fractions of protein and carbohydrate (CHO)

The $\mathrm{CP}$ and $\mathrm{CHO}$ were further partitioned using CNCPS system (Sniffen et al., 1992; Licitra et al., 1996; Yu et al., 2003). The characterization of the CP fractions in CNCPS is as follows: fraction A is NPN; fraction B is true protein; and fraction $\mathrm{C}$ is unavailable protein. Fraction $\mathrm{B}$ is further divided into three fractions (PB1, $\mathrm{PB} 2$ and $\mathrm{PB} 3$ ) that are believed to have different rates of degradation in the rumen. PB1 is a fraction of CP that is soluble in borate-phosphate buffer and precipitated with sodium tungstate. It is estimated by subtracting NPN from soluble CP. PB2 
is a fraction of true protein, soluble in neutral detergent but not soluble in buffer, it is fermentable in the rumen at a lower rate than buffer soluble fraction, and some of the PB2 escapes to lower gut. It is estimated by buffer insoluble CP minus NDICP. PB3 is insoluble in neutral detergent but soluble in acid detergent, slowly degradable true protein in the rumen because of its association with the plant cell wall, a large portion of PB3 escapes the rumen. It is estimated by the difference of NDICP and ADICP. Carbohydrate was divided into: a rapidly degradable fraction (CA), intermediately degradable fraction (CB1), a slowly degradable fraction (CB2) and unfermentable fraction (CC).

\section{Estimation of energy values}

The energy values of TDN1x, DE3x, ME3x, NE $3 x, D E 4 x, M E 4 x, N_{L} 4 x, M E$, $\mathrm{NE}_{\mathrm{m}}$ and $\mathrm{NE}_{\mathrm{g}}$ were estimated using $\mathrm{NRC}(1996,2001)$ and Weiss et al. (1992).

\section{Statistical analysis}

Statistical analyses were performed using Proc Mixed of SAS (2005). The treatment means were separated using Fisher's LSD test (Steel and Torrie, 1980) with significance set at $\mathrm{P}<0.05$.

\section{RESULTS AND DISCUSSION}

Analysed gross energy and predicted energy content are shown in Table 1. A summative method was used to derive TDN1x, DE3x, ME3x, NE $3 x$, DE4x, ME4x, $\mathrm{NE}_{\mathrm{L}} 4 \mathrm{x}$ using the NRC Dairy (2001) and Weiss et al. (1992), ME, $\mathrm{NE}_{\mathrm{m}}$ and $\mathrm{NE}_{\mathrm{g}}$ were estimated from NRC Beef(1996). CDC SO-I oat had similar gross energy values as $\mathrm{CDC}$ Dancer and Derby, but higher truly digestible neutral detergent fibre (tdNDF) and truly digestible fatty acid (tdFA) and lower truly digestible non-fibre carbohydrate (tdNFC). There was no difference in predicted energy values at $1 \mathrm{x}$, $3 \mathrm{x}$ and $4 \mathrm{x}$ production levels between CDC SO-I and conventional oat. The results indicated that CDC SO-I had higher and lower. Gross energy values were in agreement with the work of Fuhr (2006) reported as 4.649 and $4.714 \mathrm{Mcal} / \mathrm{kg}$ for Derby and LLH-HOG, respectively. The tdNDF was lower than that of reported value by the same author. Calculated energy values for CDC SO-I were similar to those reported by Yu et al. (2003) and NRC values for barley (NRC, 1996, 2001), suggesting that CDC SO-I could be an alternative to barley as a potential energy source in dairy and beef ration. 
Table 1. Predicted energy value of different cultivar of oats, Mcal $/ \mathrm{kg}$ DM

\begin{tabular}{|c|c|c|c|c|c|c|}
\hline \multirow[b]{2}{*}{ Item } & \multicolumn{3}{|c|}{ Oats } & \multirow[b]{2}{*}{ SEM } & \multicolumn{2}{|c|}{ P value } \\
\hline & $\begin{array}{c}\text { CDC } \\
\text { Dancer }\end{array}$ & Derby & $\begin{array}{l}\text { CDC } \\
\text { SO-I }\end{array}$ & & oat & year \\
\hline \multicolumn{7}{|l|}{ Gross energy } \\
\hline GE, Mcal/ kg DM & 4.5748 & 4.5652 & 4.6018 & 0.01116 & 0.2183 & 0.6258 \\
\hline \multicolumn{7}{|c|}{ Digestible nutrients (NRC, 2001), \%DM } \\
\hline $\operatorname{tdNDF}$ & $11.44^{\mathrm{b}}$ & $13.55^{\mathrm{b}}$ & $18.06^{\mathrm{a}}$ & 0.357 & 0.0111 & 0.4221 \\
\hline $\mathrm{tdNFC}$ & $56.19^{\mathrm{a}}$ & $54.94^{\mathrm{a}}$ & $47.66^{\mathrm{b}}$ & 0.621 & 0.0179 & 0.2218 \\
\hline $\operatorname{tdCPc}$ & 11.58 & 10.90 & 12.59 & 0.304 & 0.1136 & 0.3667 \\
\hline tdFA & $3.57^{\mathrm{b}}$ & $3.01^{\mathrm{b}}$ & $4.85^{\mathrm{a}}$ & 0.153 & 0.0259 & 0.2665 \\
\hline \multicolumn{7}{|c|}{ Total digestible nutrient } \\
\hline TDN1x, \% & 80.23 & 79.45 & 82.20 & 0.798 & 0.2102 & 0.8631 \\
\hline \multicolumn{7}{|c|}{ Predicted energy at production level of intake (3x) (NRC Dairy Model 2001), Mcal/kg DM } \\
\hline DE3 $x$ & 3.2362 & 3.1862 & 3.3247 & 0.03403 & 0.1889 & 0.7667 \\
\hline ME3x & 2.8258 & 2.7727 & 2.9210 & 0.03500 & 0.1861 & 0.8277 \\
\hline NEL3x & 1.8040 & 1.7640 & 1.8773 & 0.02646 & 0.1842 & 0.7745 \\
\hline \multicolumn{7}{|c|}{ Predicted energy at production level of intake (4x) (NRC Dairy Model, 2001), Mcal/kg DM } \\
\hline DE4x & 3.0924 & 3.0446 & 3.1769 & 0.03434 & 0.2100 & 0.7667 \\
\hline ME4x & 2.6806 & 2.6297 & 2.7718 & 0.03500 & 0.1861 & 0.8277 \\
\hline NEL4 $\mathrm{x}$ & 1.7017 & 1.6633 & 1.7720 & 0.02466 & 0.1615 & 0.6857 \\
\hline \multicolumn{7}{|c|}{ Net energy estimated from NRC Beef Model, 1996, Mcal $/ \mathrm{kg}$ DM } \\
\hline ME & 2.8896 & 2.8449 & 2.9685 & 0.03500 & 0.2341 & 0.8277 \\
\hline $\mathrm{NE}_{\mathrm{m}}$ & 1.9398 & 1.9023 & 2.0055 & 0.02466 & 0.1911 & 0.6857 \\
\hline $\mathrm{NE}_{\mathrm{g}}$ & 1.2947 & 1.2623 & 1.3511 & 0.02263 & 0.1948 & 0.8297 \\
\hline
\end{tabular}

SEM - standard error of mean

means with the different letters in the same row are significantly different $(\mathrm{P}<0.05)$

Protein and carbohydrate fractions determined by the CNCPS system (Sniffens et al., 1992) are shown in Table 2. CDC SO-I oat had similar protein fractions as CDC Dancer and Derby except for PB2. Considerably less PB2 (\%CP) in CDC SO-I was observed than for CDC Dancer and Derby, indicating less slowly digestible protein and more for rumen microbial protein synthesis. CDC SO-I oat had less total $\mathrm{CHO}$ and $\mathrm{CC}$ fraction, but higher $\mathrm{CB} 2$ fractions than CDC Dancer and Derby. The results indicated that CDC SO-I had more slowly digestible carbohydrate and less undigestible carbohydrates associated with the cell walls than CDC Dancer and Derby. Compared to the barley study using CNCPS by Yu et al. (2003), oat had more $\mathrm{PA}+\mathrm{PB} 1+\mathrm{PB} 2$ and less $\mathrm{PB} 3$ and $\mathrm{PC}$ fractions. Such results suggest that oat has more readily degradable $\mathrm{CP}$ in the rumen. 
Table 2. Protein and carbohydrate fractions (CNCPS) of different cultivar of oats

\begin{tabular}{|c|c|c|c|c|c|c|}
\hline \multirow{2}{*}{ Item } & \multicolumn{3}{|c|}{ Oats } & \multirow{2}{*}{ SEM } & \multicolumn{2}{|c|}{$P$ value } \\
\hline & CDC Dancer & Derby & CDC SO-I & & oat & year \\
\hline \multicolumn{7}{|c|}{ Protein fractions } \\
\hline \multicolumn{7}{|l|}{$\% C P$} \\
\hline PA & 13.43 & 9.88 & 15.62 & 1.569 & 0.227 & 0.118 \\
\hline PB1 & 30.00 & 36.17 & 37.51 & 3.311 & 0.406 & 0.461 \\
\hline PB2 & $46.17^{\mathrm{a}}$ & $47.01^{\mathrm{a}}$ & $40.38^{\mathrm{b}}$ & 0.510 & 0.020 & 0.976 \\
\hline PB3 & 5.34 & 2.38 & 2.32 & 0.701 & 0.141 & 0.284 \\
\hline $\mathrm{PC}$ & 5.07 & 4.57 & 4.18 & 1.636 & 0.932 & 0.941 \\
\hline \multicolumn{7}{|l|}{$\% D M$} \\
\hline PA & 1.59 & 1.09 & 2.01 & 0.239 & 0.214 & 0.189 \\
\hline PB1 & 3.54 & 4.03 & 4.80 & 0.411 & 0.295 & 0.355 \\
\hline PB2 & 5.46 & 5.22 & 5.17 & 0.124 & 0.395 & 0.297 \\
\hline PB3 & 0.63 & 0.26 & 0.30 & 0.082 & 0.140 & 0.233 \\
\hline $\mathrm{PC}$ & 0.60 & 0.51 & 0.54 & 0.196 & 0.942 & 0.896 \\
\hline \multicolumn{7}{|c|}{ Carbohydrate fractions } \\
\hline \multicolumn{7}{|l|}{$\% D M$} \\
\hline $\mathrm{CHO}$ & $80.44^{\mathrm{a}}$ & $81.75^{\mathrm{a}}$ & $77.77^{\mathrm{b}}$ & 0.419 & 0.041 & 0.202 \\
\hline \multicolumn{7}{|l|}{$\% \mathrm{CHO}$} \\
\hline $\mathrm{CA}$ & 11.65 & 16.65 & 5.39 & 3.104 & 0.233 & 0.444 \\
\hline CB1 & 56.89 & 49.30 & 54.74 & 2.347 & 0.265 & 0.441 \\
\hline $\mathrm{CB} 2$ & $19.80^{c}$ & $23.51^{\mathrm{b}}$ & $33.35^{\mathrm{a}}$ & 0.508 & 0.005 & 0.207 \\
\hline $\mathrm{CC}$ & $11.67^{\mathrm{a}}$ & $10.55^{\mathrm{a}}$ & $6.53^{b}$ & 0.498 & 0.033 & 0.685 \\
\hline \multicolumn{7}{|l|}{$\% D M$} \\
\hline $\mathrm{CA}$ & 9.38 & 13.59 & 4.20 & 2.392 & 0.206 & 0.422 \\
\hline CB1 & 45.76 & 40.31 & 42.57 & 2.050 & 0.359 & 0.583 \\
\hline CB2 & $15.93^{c}$ & $19.22^{\mathrm{b}}$ & $25.93^{\mathrm{a}}$ & 0.488 & 0.009 & 0.370 \\
\hline $\mathrm{CC}$ & $9.39^{\mathrm{a}}$ & $8.63^{\mathrm{a}}$ & $5.08^{\mathrm{b}}$ & 0.446 & 0.036 & 0.597 \\
\hline
\end{tabular}

SEM - standard error of mean

means with the different letters in the same row are significantly different $(\mathrm{P}<0.05)$

\section{CONCLUSIONS}

The CDC SO-I oat contained similar protein fractions as CDC Dancer and Derby except for PB2. Considerable less PB2 (\%CP) in CDC SO-I was observed, indicating less slowly digestible protein and more for rumen microbial protein synthesis. CDC SO-I oat had less total $\mathrm{CHO}$ and $\mathrm{CC}$ fraction, but higher CB2 fractions than CDC Dancer and Derby. The results indicated that CDC SO-I oat had more slowly digestible carbohydrate and less undigestible carbohydrates associated with the cell walls than CDC Dancer and Derby. CDC SO-I had similar energy values as barley, suggesting that CDC SO-I could be a good alternative as an energy concentrate in dairy and beef rations. 


\section{REFERENCES}

AOAC, 1990. Association of Official Analytical Chemists, Official Methods for Analysis. $15^{\text {th }}$ Edition. Arlington, VA

Crosbie G.B., Tarr A.W., Portmann P.A., Rowe J.B., 1985. Variation in hull composition and digestibility among oat genotypes. Crop Sci. 25, 678-680

Fisher L.J., Logan V.S., 1969. Comparison of corn and oat based concentrates for lactating dairy cows. Can. J. Anim. Sci. 49, 85-90

Fuhr L.G., 2006. Low lignin hull, high oil groat oat grain in lactating dairy cow ration. Master Thesis, University of Saskatchewan (Canada)

Licitra G., Hernandez T.M., Van Soest P.J., 1996. Standardization procedures for nitrogen fractionation of ruminant feeds. Anim. Feed Sci. Tech. 57, 347-358

Martin P.A., Thomas P.C., 1987. Reduction in the saturated fatty acid content of cows' milk fat through diet formulation. Proc. Nutr. Soc. 46, 114A (Abstr.)

McCleary B.V., Gibson T.S., Mugford D.C., 1997.Measurement of total starch in cereal products by amyloglucosidase - alpha-amylase method: Collaborate study. J. AOAC Int. 80, 571-579

Moran J.B., 1983. Barley, wheat or oats grain as cereal sources for dairy cows. In: G.F. Robards, R.G. Packham (Editors). Feed Information and Animal Production. Proceedings of the $2^{\text {nd }}$ Symposium of the International Network of Feed Information Centres. Commonwealth Agriculture Bureau, pp. 429

Moran J.B., 1986. Cereal grains in complete diets for dairy cows: A comparison of rolled barley, wheat and oats and of three methods of processing oats. Anim. Prod. 43, 27-36

NRC, 1996. Nutrient Requirements of Beef Cattle. National Research Council. $7^{\text {th }}$ revised Edition. National Academy Press. Washington, DC

NRC, 2001. Nutrient Requirements of Dairy Cattle. National Research Council. $7^{\text {th }}$ revised Edition. National Academy Press. Washington, DC

SAS, 2005. SAS/STAT User's Guide. Version 9.1. SAS Institute Inc. Cary, NC

Schingoethe D.J., Voelker H.H., Ludens F.C., 1982. High protein oats for lactating dairy cows and growing calves. J. Anim. Sci. 55, 1200-1205

Sniffen C.J., O’Connor J.D., Van Soest P.J., Fox D.G., Rusell J.B., 1992. A net carbohydrate and protein system for evaluation cattle diets. II. Carbohydrate and protein availability. J. Anim. Sci. $70,3562-3577$

Steel R.G., Torrie J.H., 1980. Principles and Procedures of Statistics. McGraw-Hill, New York, NY

Tommervik R.S., Waldern D.E., 1969. Comparative feeding value of wheat, corn, barley, milo, oats, and a mixed concentrate ration for lactating cows. J. Dairy Sci. 52, 68-73

Van Soest P.J., Robertson J.B., Lewis B.A., 1991. Methods for dietary fiber, neutral detergent fiber, and non-starch polysaccharides in relation to animal nutrition. J. Dairy Sci. 74, 3583-3597

Weiss W.P., Conrad H.R., St. Pierre N.R., 1992. Theoretically-based model for predicting nutrient values of forages and concentrates. Anim. Feed Sci. Tech. 39, 95-110

Yu P., Meier J.A., Christensen D.A., Rossnagel B.G., McKinnon J.J., 2003. Using the NRC-2001 model and the DVB/OEB system to evaluate nutritive values of Harrington (malting-type) and Valier (feed type) barley for ruminants. Anim. Feed Sci. Tech. 107, 45-60 